there were "no alignments to realign from"; few Americans possessed stable party commitments. Aligning episodes could take place only after 1838, when stable, predictable voting coalitions had established themselves. For Silbey, the period from 1838 to 1893 represents one era, interrupted only by realignment in the pre-civil war period. What looms large, however, are the "rock-like party loyalties" of the citizenry.

According to Silbey, the early 1890s saw the reshaping of the party system. While advocates of realignment theory might focus on shifting coalitions, Silbey emphasized the destruction of the parties' central role in the political system as the key ingredient. The new era ushered in declining voter turnout, ticket splitting, and greater electoral instability. The realignment associated with the New Deal could only delay but not end party decline. Indeed, Silbey views the post-1934 era as one of "post-realignment," with the phenomenon consigned to the dust heap of history.

Ladd's paper compared the 35-year preoccupation with realignment to "waiting for Godot." Suggesting that the concept is too confining and deflects attention from changes in the party system, Ladd proposed that research address questions that focus on changes in the relationships between issues and cleavages, the social and ideological make-up of society, and party organization, including nominations and campaigning.

For Ladd, party eras are distinctive because of changes in society-changes in the mass media, educational levels, occupational structures, the civil rights revolution, and generational change. New societal eras can generate new party systems even though the political world stubbornly refuses to produce the large-scale partisan changes associated with realigning elections.

Shafer also expressed dissatisfaction with the concept of realignment. He called the preoccupation election after election with realignment "an intellectual waste." He asserted that a stable electoral order had emerged out of the 1960s, with a Republican-controlled White House, a generally Democratic Senate, and a solidly Democratic House of Representatives.
Societal divisions underlie this pattern and find expression in the presidency, an institution which symbolizes cultural values and foreign policy, and in Congress, the symbol of welfare, service, and individual benefits. The American political system thus neatly accommodates inconsistencies, crosscutting preferences and social divisions, and realignment has "nothing to say about this stable pattern."

Burnham defended realignment models, noting that " 30 years is a short time in the history of an idea." He contended that the "wells of creativity in this area have not yet run dry" and that no model of largescale change could succeed without incorporating punctuated change as an important feature. Moreover, in contrast to Ladd's "waiting for Godot" posture or Silbey's "post-realignment era," Burnham asserted that the 1968-72 period did involve realignment and that it was "right on time.'

Warning against predictions that realigning elections are phenomena of a bygone era, McSeveney pointed out that the realigning election of 1932 would have been unforeseen in 1928, just as the coming of a Republican-presidential era had been unexpected. He saw the concept of realignment as a necessary but not sufficient explanation for understanding the evolution of the American electoral system.

The Lasswell Symposium thus explored a diversity of views concerning the adequacy of the idea of realignment for understanding the electoral order.

Note

1. Ladd could not be present and his paper was delivered by Harold Bass, Jr.

\section{Dahl Receives 1989 Lippincott Award}

\section{Devon Groves \\ American Political Science Association}

Robert A. Dahl of Yale University received the Benjamin A. Lippincott Award for a work of exceptional quality by a living 


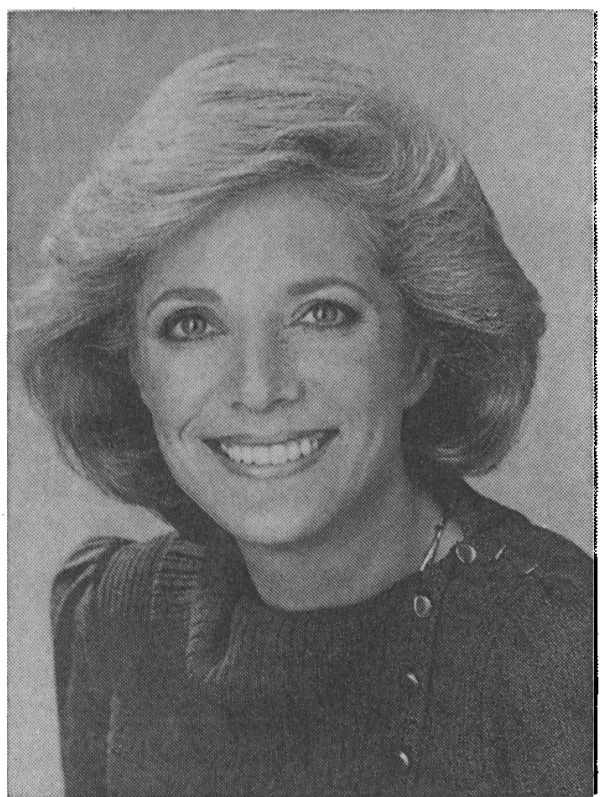

Leslie Stahl of CBS News received the $198 \overline{9}$ Carey McWilliams Award. Stahl donated her award to the political science department of Wheaton College.

political theorist that is still considered significant after a time span of at least 15 years since the original publication. The biannual award recognized Dahl's book, $A$ Prefoce to Democratic Theory, first published by the University of Chicago Press in 1956.

General Brent Scowcroft and Lesley Stahl were also among those honored at

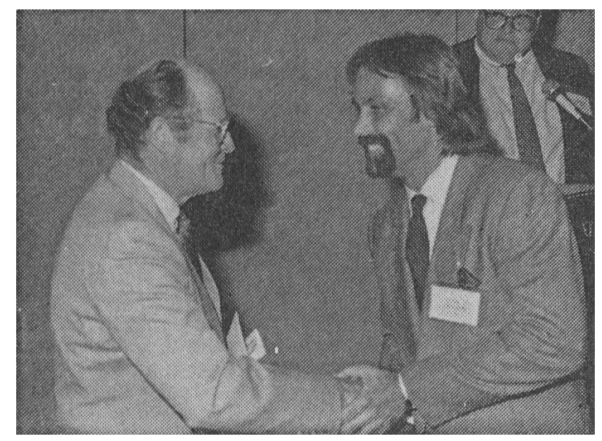

Charles O. Jones (1.) presents the 1989 Heinz Eulau award to James E. Gibson. the APSA's 85th annual meeting. General Scowcroft, assistant to the president for National Security Affairs, the White House, was honored with the Hubert $H$. Humphrey Award for notable public serv. ice by a political scientist. Lesley Stahl of CBS News received the Carey McWilliams Award presented each year to honor a major journalistic contribution to our understanding of politics.

James E. Gibson of the University of Houston received the second annual Heinz Eulau Award for the best published article in The American Political Science Review during 1988. Gibson was recognized for the article, "Political Intolerance and Political Repression During the McCarthy Red Scare."

For the best book published in the United States during the past year on government, politics or international affairs, the Woodrow Wilson Foundation Award went to Larry Bartels of the University of Rochester. The winning book was Presidential Primaries and the Dynamics of Public Choice, published by Princeton University Press.

Thomas J. Anton was awarded the Gladys Kammerer Award for his book, American Federalism and Public Policy, the best political science publication in the field of U.S. national policy, published the previous year.

The Ralph ]. Bunche Award for a scholarly work exploring the phenomena of ethnic and cultural pluralism was received by Ronald Walters of Howard University for his book, Black Presidential Politics in America: A Strategic Approach.

The Franklin L. Burdette Pi Sigma Alpha Award went to the authors of the best paper presented at the 1988 Annual Meeting, "New Players in an Old Game." George Rabinowitz and Stuart Elaine Macdonald of the University of North Carolina, and Ola Listhaug of the University of Trondheim received this distinction.

Aaron Wildavsky, University of . California, Berkeley, was honored as the John Gaus Lecturer. Professor Wildavsky delivered the lecture, "Joseph the Administrator" at the annual meeting. The lecture has been reprinted in this issue of PS.

In addition, the Association also awarded eight dissertation awards for 
works completed and accepted during 1987 or 1988.

The Gabriel A. Almond Award for the best doctoral dissertation in the field of comparative politics went to two recipients: Jeffery Herbst of Princeton University for his dissertation Policy Formulation and Implementation in Zimbabwe: Understanding State Autonomy and the Focus of Decision-Making, submitted by Yale University; dissertation chair, William Foltz; and Sven Steimno of the University of Colorado for Taxes, Institutions and the Mobilization of Bias: The Political Economy of Taxation in Britain. Sweden and the United States, submitted by the University of California, Berkeley; dissertation chair, Aaron Wildavsky.

The William Anderson Award for the field of intergovernmental relations went to John C. Drew of Williams College for the dissertation Child Labor and Child Welfare: The Origins and Uneven Development of the American Welfare State, submitted by Cornell University; dissertation chair, Ronald King.

Mark Graber of the University of Texas at Austin received the Edward S. Corwin Award for the doctoral dissertation in the field of public law. His dissertation, entitled The Transformation of the Modern Constitutional Defense of Free Speech, was submitted by Yale University; dissertation chair, Rogers Smith.

The Harold D. Lasswell Award for outstanding dissertations in the field of policy studies went to two recipients this year: Carol Hager of the University of California, San Diego, for Technological Democracy: Bureaucracy and Citizenry in the West German Energy Debate, submitted by the University of California, San Diego; dissertation chair, David Laitin; and John Mark Hansen of the University of Chicago for

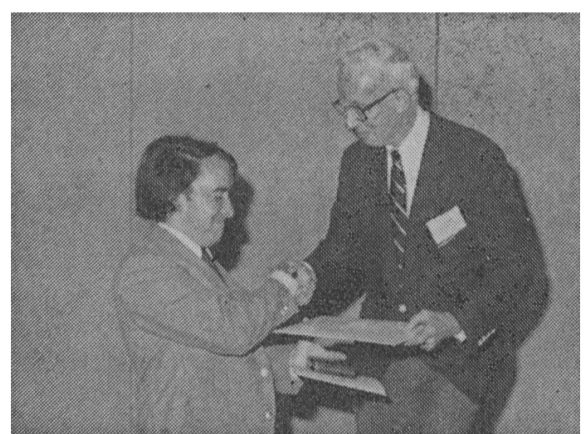

Larry Bartels (I.) receives the 1989 Woodrow Wilson Foundation Award from Frank Sorauf.

Creating New Politics: The Evolution of an Agricultural Policy Network in Congress, 1919-1980, submitted by Yale University; dissertation chair, David Mayhew.

The Helen Dwight Reid Award for the field of international relations, law and politics was received by Yossi Shain, Tel Aviv University, for the dissertation, In Search of Loyalty and Recognition: The Political Activities of Exiles, submitted by Yale University; dissertation chair, Juan Linz.

In the field of American government, the E. E. Schattschneider Award was given to Victoria C. Hattam of Yale University for the dissertation, Unions and Politics: The Courts and American Labor: 1806-1896, submitted by the Massachusetts Institute of Technology; dissertation chair, Suzanne Berger.

Property Rights and Constitutional Order in Imperial China, by Tai-Shuenn Yang of the National Cheng-Chi University, received the Leo Strauss Award for the field of political philosophy. The dissertation was submitted by Indiana University; dissertation chairs, Vincent Ostrom and Jean Robinson.

\section{Nominations Sought for 1990 APSA Awards}

Nominations are invited for the APSA awards to be presented at the 1990 annual meeting in San Francisco. Dissertations must be nominated by departments and submitted by January 15, 1990. Books must be nominated by publishers and submitted by February 1, 1990. Members are invited to nominate individuals for the career awards. Further details may be obtained by contacting the national office. 


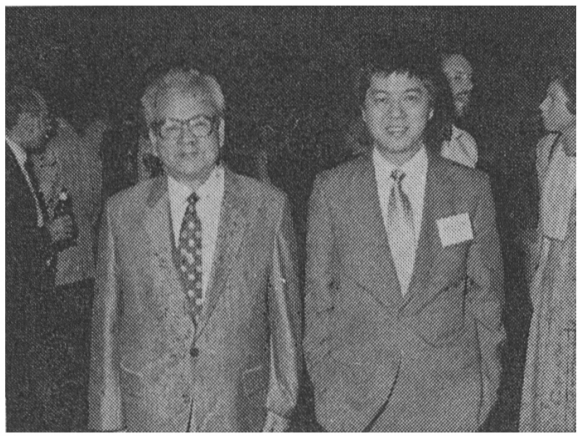

Tai-Shuenn Yang (r.) pictured here with his father, received the Leo Strauss Award for the best dissertation in the field of political philosophy.

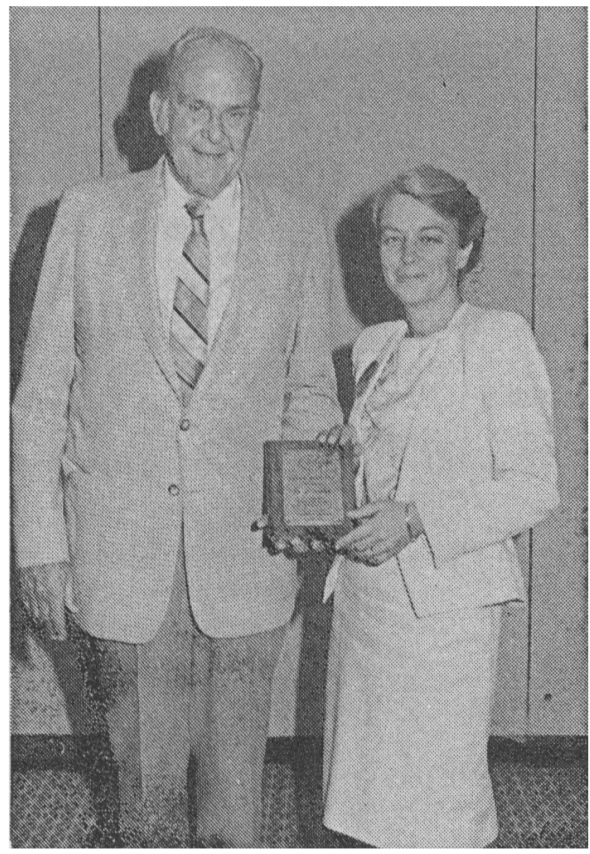

Trudi Miller presents the Policy Studies Section's Donald Campbell Award to Donald Campbell.

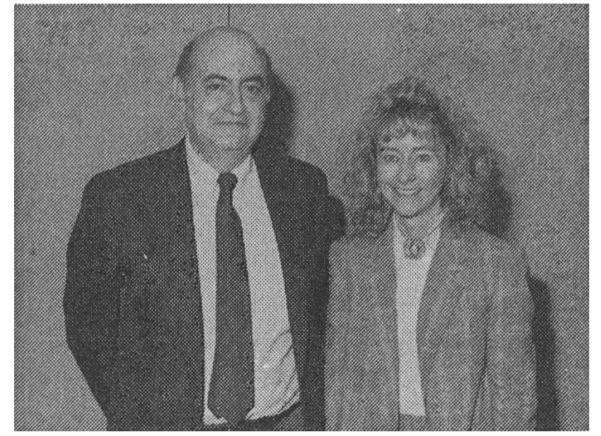

Joseph Cooper and Cheryl Young, recipients of the Legislative Studies Section's CQ Award.

The Leonard D. White Award for the field of public administration was awarded to Roy $T$. Meyers of the Congressional Budget Office for his dissertation, Microbudgetary Strategies and Outcomes, submitted by the University of Michigan; dissertation chair, John Kingdon.

Editor's Note: For the full text of citations, see the Gazette in this issue of PS.

\section{APSA Sections Distribute Awards at 1989 Annual Meeting}

The Policy Studies Section presented the Donald Campbell Award for an outstanding methodological innovator in public policy to Donald Campbell of Lehigh University. Trudi Miller, University of Minnesota, received the Policy Studies Organization Paper Award for the best policy studies paper presented at the 1988 Annual Meeting; her paper was entitled, "Designing Social Structures: A Scientific Perspective." The Section's Hubert $H$. Humphrey Award for outstanding scholarship contributing to the understanding public policy practitioner was posthumously awarded by Dale Rogers Marshall of Wellesley College to Charles Levine. Martha Derthick of the University of Virginia was presented with 